\title{
Gebeliğin İntrahepatik Kolestazının \\ Maternal ve Perinatal Sonuçlara Etkisinin Değerlendirilmesi
}

The Effect of Intrahepatik Cholestasis of Pregnancy on Maternal and Perinatal Outcomes

Mehmet Bayrak, Taner Günay, Cihan Karadağ, Zelal Balçık

İstanbul Medeniyet Üniversitesi Göztepe Eğitim ve Araştırma Hastanesi, Kadın Hastalıkları ve Doğum Kliniği

\section{ÖZET}

Amaç: Gebeliğin intrahepatik kolestazı tanısıyla takip edilen hastaların maternal ve perinatal sonuçlarının değerlendirilmesi ve uygun gebelik yönetiminin tartışılması amaçland.

Gereç ve Yöntemler: Ocak 2009 ve Aralık 2013 yllart arasında gebeliğin intrahepatik kolestazı tanısı alan 32 hastanin dosyalarına retrospektif olarak ulaşılarak maternal ve perinatal sonuçlar açısından analiz edildi.

Bulgular: Toplam 32 hasta çalışmaya dahil edildi. Gebeligin intrahepatik kolestazl ortalama tanı haftasi

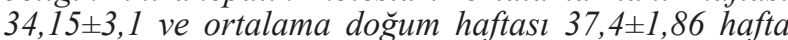
olarak bulundu. Preterm doğum oranı (doğumda gebelik haftasl <37) \%20,59 (7/34 yenidoğan) olarak saptandl. Ortalama doğum ăgırlığ $2980 \pm 480$ gram idi. Yenidoğanların \%14,7'nin doğumda 5. dakika APGAR skorunun 7'nin altında olduğu izlendi. Yenidoğanların $\% 14,7$ 'sinde amnion mayisinde mekonyum pasaji izlendi. Dört $(\% 12,5)$ yenidoğanın yoğun bakım ünitesine gönderilme gereksinimi oldu. Perinatal mortalite saptanmadi. Gebeligin intrahepatik kolestazı tanıl hastalarda gestasyonel diyabetes mellitus insidansının \%15,6 olduğu izlendi.

Sonuç: Çalışmamı gebeliğin intrahepatik kolestazı tanılı gebelerde preterm doğum riskinin arttığını doğrulamaktadır. Gebeliğin intrahepatik kolestazı tanıl hastalarda gestasyonel diyabetes mellitus riskinin artmis olması da hastalı̆̆ın yönetiminde dikkate alınmasi gereken bir durum olduğunu düşünmekteyiz.

Anahtar Kelimeler: gebeliğin intrahepatik kolestazl, maternal ve perinatal sonuçlar, gestasyonel diyabetes mellitus

\section{ABSTRACT}

Objective: To evaluate maternal and perinatal outcomes of the pregnancies complicated by intrahepatic cholestasis of pregnancy and to discuss the appropriate pregnancy management.

Materials and Methods: Maternal and fetal characteristics were analyzed from the medical records of $32 \mathrm{pa}$ tients who gave birth following a pregnancy complicated with intrahepatic cholestasis of pregnancy between January 2009 and December 2013.

Results: A total of 32 patients with intrahepatic cholestasis of pregnancy were enrolled the study. Diagnosis of intrahepatic cholestasis was made at an average of $34.15 \pm 3.1$ gestational weeks and mean gestational time at birth was found to be $37.4 \pm 1.86$ gestational weeks. Preterm birth rate ( $<37$ gestational weeks) was $20.59 \%$. Mean birth weight and a low $(<7)$ 5- minute APGAR score were $2980 \pm 480 \mathrm{~g}$., and $14.70 \%$, respectively. Meconium was detected in amniotic fluid in $14.70 \%$ of the cases and admission rate to neonatal care unit was $12.50 \%$. There were no reported cases of stillbirth. The incidence of gestational diabetes mellitus in intrahepatic cholestasis of pregnancy was $15.62 \%$.

Conclusion: Our data confirm an increased risk of preterm delivery in intrahepatic cholestasis of pregnancy. The high rates of gestational diabetes mellitusis need to be considered in the management of intrahepatic cholestasis of pregnancy.

Keywords: intrahepatik cholestasis of pregnancy, maternal and perinatal outcomes, gestational diabetes mellitus

\footnotetext{
İletişim Bilgileri:

Yazışmadan Sorumlu Yazar: Mehmet BAYRAK

Yazışma Adresi: Göztepe Eğt. ve Arş. Hast. Kadın Hast. ve Doğ. Kliniği, Fahrettin K. Gökay Cd. Kadıköy, İstanbul Tel: +90 (216) 5664000

E-mail: drmehmetbayrak@gmail.com

Makalenin Geliş Tarihi: 12.09.2014

Makalenin Kabul Tarihi: 22.04.2015

DOI: http://dx.doi.org/10.16948/zktb.37157
} 


\section{GİRİŞ}

Gebeliğin intrahepatik kolestazı (GİK) gebelikte en sık gözlenen karaciğer hastalığıdır. Yaygınlığ 1 genetik ve çevresel faktörlerden etkilenmektedir. Çalışılan popülasyon ve ülkelere göre değişmekle beraber, insidans $1 \% 0,4$ 'ten $\% 15$ 'e kadar genis bir aralikta bildirilmektedir [1]. Tanı genellikle gebeliğin ikinci yarısında başlayan kaşıntı ile birlikte karaciğer fonksiyon testleri ve/veya serum safra asitleri seviyelerinde yükseklik ile konulmaktadır. Aynı zamanda kaşıntıya neden olan dermatolojik hastalıkların ve karaciğer enzim yüksekliğine yol açan hastalıkların dișlanması gerekmektedir [2]. Postpartum 4 hafta içerisinde kaşıntı şikayeti gerilemekte ve karaciğer enzimleri sekel birakmadan normal düzeylerine gerilemektedir.

Bu gebeliğe özgü karaciğer disfonksiyonun etyopatogenezinde hormonal, genetik ve çevresel faktörler suçlanmakla birlikte etiyolojisi kesin olarak bilinmemektedir. Geceleri şiddetlenen kaşıntıya bağlı uykusuzluk dıșında ciddi maternal morbidite ve mortalitenin izlenmediği intrahepatik kolestaz olgularında maternal durumun aksine fetal morbidite ve mortalite artmıştır. GİK'in asıl önemi fetal iyilik halini takip etmede kullanilan testlerle tespit edilemeyen ani intrauterin fetal ölümlere neden olabilmesidir. 1970'lerde ki başlangıç çalıșmalarında GİK'in spontane ve/veya iyatrojenik preterm doğum, mekonyum ile boyalı amniyotik mayi ile fetal ölüme sebep olduğu bildirilmesi nedeniyle geçmişten günümüze kadar GİK yönetiminde, yaygın olarak gebeliğin 39.haftasından önce doğum indüksiyonu uygulanmaktadır [3]. Güncel literatürde ise GİK sonucunda preterm doğum oranında artış olmasına rağmen fetal ölüm riskinde artış olmadığını bildiren geniş toplum bazlı çalışmalar yayınlanmıştır $[4,1]$.

GİK yönetiminde ideal bir fetal izlem ve doğum yönetim protokolü oluşturulamamıştır. Bu çalıșmada kliniğimizde GIKK tanısı ile izlem ve tedavisi yapılan 32 gebenin sonuçlarının değerlendirilmesini ve gebelik yönetiminin güncel literatür bilgileri aracılığıyla tartışılmasını amaçladık.

\section{GEREÇ ve YÖNTEM}

Medeniyet Üniversitesi Göztepe Eğitim ve Araştırma Hastanesi Kadın Hastalıkları ve Doğum Kliniğinde Ocak 2009 ile Aralık 2013 tarihleri arasında gebelik takipleri yapılan tüm gebelerin tıbbi kayıtları geriye dönük taranarak, GİK tanısı almış olan hastaların dosyaları incelendi. GIKK tanısı konulması için gerekli kriterler; (1) dermatolojik patoloji olmaksızın kaşıntı olması, (2) laboratuvar bulgularının
GİK kliniğini destekliyor olması (serum Aspartat Aminotransferaz (AST), serum Alanin Aminotransferaz (ALT) konsantrasyonları $>40$ U/L), (3) karaciğer ve safra kesesinin ultrasonografik olarak normal sinırlarda görüntülenmesi (4), hepatit A, B, C serolojisinin negatif saptanmasi olarak belirlendi. Preeklampsi ya da hipertansiyon öyküsü ve gebelik öncesi karaciğer hastalık öyküsü bulunan olgular çalıșmaya dâhil edilmedi. GIKK tanısı alan hastalara tanı anındaki gebelik haftası, semptomlar, karaciğer fonksiyon testleri ve fetal iyilik durumları değerlendirilerek ursodeoksikolik asit (UDKA) tedavisi (10-15 mg/kg/gün) başlanmıştır. İzlem sirasında, NST' de fetal distress veya karaciğer aminotransferaz düzeylerinde normalden 10 kat artış durumunda gebelik haftasından bağımsız olarak doğum eylemi başlatıldı. Tedaviye rağmen şikayetleri gerilemeyen ve karaciğer aminotransferaz düzeylerinde yükselme devam eden hastalara gebeliğin 37 . Haftasından sonra doğum indüksiyonu planlandı. Hastaların obstetrik öyküleri, eşlik eden hastalıklar, karaciğer aminotransferaz düzeyleri, doğum haftasi, doğum şekli, yenidoğanın 5. dakika APGAR skoru ve doğum ağırlığı verileri dosya kayıtlarından elde edildi. Laboratuvar koşulları nedeniyle serum safra asitleri düzeyine bakılamadığ1 için bu veri dosya kayıtlarından sağlanamamıştır. Tekil gebelikler için 37. gebelik haftasından önceki doğumlar, ikiz gebelikler için ise 36 . gebelik haftasından önceki doğumlar preterm doğum olarak kabul edildi. Verilerin değerlendirilmesinde tanımlayıc1 istatistiksel metotlar kullanıldı. İstatistikî analiz için tüm veriler Statistical Package for the Social Sciences (SPSS 21) programına aktarılarak belirtilen amaçlar doğrultusunda hesaplandi.

\section{BULGULAR}

Çalışma kriterlerini sağlayan toplam 32 hasta değerlendirildi. Olguların yașı, gravida ve paritelerinin ortalama \pm standart sapma, minimum-maksimum değerleri sirasıyla $28,03 \pm 5,10$ (19-38) , 1,88 $\pm 0,96(1-5), 0,62 \pm 0,74$ (0-3) olarak saptand1. Hastaneye kabulde hastaların ortalama gebelik haftası $34,15 \pm 3,1$ hafta, doğumdaki ortalama gebelik haftasi $37,4 \pm 1,86$ hafta olarak bulundu. Olguların ikisinde ikiz gebelik mevcuttu. Olguların \%68,75'inin $(n=22)$ primipar, \%31,25'nin (n=10) multipar olduğu tespit edildi. Multipar olguların \%30'unda $(n=3)$ obstetrik özgeçmişlerinde GIKK öyküsü mevcuttu. İki olguda ise obstetrik özgeçmişlerinde gebeliğin son ayında başlamış tanı konulmamıș pruritus öyküsü mevcuttu. Tanı sonrası en yüksek AST ve ALT düzeyleri sirasıyla ortalama 174 \pm 112 (39-642) IU/L, 242 \pm 124 (62-684) IU/L olarak tespit edildi. Çalışma grubumuza ait tanımlayıcı veriler Tablo 1' de gösterilmiştir. 
Tablo 1. Olguların demografik özellikleri.

\begin{tabular}{|l|l|}
\hline Yaş & Ortalama \pm SS (min-max) \\
\hline Gravida & $28,03 \pm 5,10(19-38)$ \\
\hline Parite & $1,88 \pm 0,96(1-5)$ \\
\hline Tanıda gebelik haftası & $0,62 \pm 0,74(0-3)$ \\
\hline AST (IU/L) & $34,15 \pm 3,1(28-40)$ \\
\hline ALT (IU/L) & $174 \pm 112(39-642)$ \\
\hline
\end{tabular}

AST: Aspartat Aminotransferaz, ALT: Alanin Aminotransferaz, SS: Standart Sapma.

Olguların \%56,25'i (n=18) sezaryen, $\% 43,75^{\prime} i \quad(n=14)$ vaginal yolla doğum yapmıştır. En sık sezaryen endikasyonu \% 27,8 $(\mathrm{n}=5)$ oran ile eski sezaryen skarı olarak saptand1. Bunu \% 22,2 ( $\mathrm{n}=4)$ oran ile fetal distress ve yine aynı oranda sefalopelvik uyumsuzluk izledi. Çalışma grubundaki olgular, GİK tanıs1 dıșında esslik eden hastalıklar açısından değerlendirildiğinde; beş hastada $(\% 15,62)$ gestasyonel diyabetes mellitus (GDM), 2 hastada lumbal disk herniasyonu, 1 hastada epilepsi ve 1 hastada myasthenia gravis hastalığ 1 tanısı olduğu saptandı. Yenidoğan sonuçları açısından değerlendirildiğinde; ortalama doğum tartısı $2980 \pm 480$ gram olarak saptand1. Preterm doğum oran1 (doğumda gebelik haftas1<37) \%20 ,59 (7/34 yenidoğan) olarak saptandı. Olguların $\% 14,7$ 'sinde $(\mathrm{n}=5)$ amnion mayisinde mekonyum pasajı izlendi. Beş yenidoğanın $(\% 14,70)$ doğumda 5. dakika APGAR skorunun 7'nin altında olduğu izlendi. Dört $(\% 12,5)$ yenidoğanın yoğun bakım ünitesine gönderilme gereksinimi oldu. Perinatal mortalite ise saptanmadı. Çalışma grubumuza ait yenidoğan sonuçları Tablo 2'de gösterilmiştir.

Tablo 2. Gebeliğin intrahepatik kolestazı tanısı alan olguların yenidoğan sonuçları.

Ortalama $\pm \mathrm{SS} / \mathrm{n}(\%) /(\mathrm{min}-$

$\max )$

\begin{tabular}{|l|l|}
\hline Doğum ağırlığı (gram) & $2980 \pm 480(1360-4240)$ \\
\hline Doğum gebelik haftası & $37,4 \pm 1,86(32-40)$ \\
\hline Sezaryen Doğum & $18(56,25 \%)$ \\
\hline $\begin{array}{l}\text { Mekonyum boyalı } \\
\text { amniyon mayi }\end{array}$ & $5(14,70 \%)$ \\
\hline $\begin{array}{l}\text { Preterm Doğum } \\
\text { 5.dk APGAR skoru<7 }\end{array}$ & $7(20,59 \%)$ \\
\hline Yenidoğan ünitesine kabul & $4(14,70 \%)$ \\
\hline
\end{tabular}

GDM komorbiditesi olan 5 olgumuz ayr1ca değerlendirildiğinde, 4 olgunun primipar, bir olgunun ise multipar olduğu tespit edildi. Üç olgunun kan şekeri değerlerinin diyet düzenlenmesi ile normal sınırlarda olduğu, iki olguda ise insülin ile kan şekeri regülasyonun sağlandığ1 saptandı. GDM tanisı olan 4 olgumuz sezaryen ile bir olgu ise vajinal yolla doğum yapmıştır. $\mathrm{Bu}$ olgularda sezaryen endikasyonlarının ikisinin fetal distress, diğerlerinin ise sefalopelvik uyumsuzluk ve eski sezaryen kesisi olduğu tespit edildi. GDM komorbiditesi olan annelerin yenidoğan sonuçları incelendiğinde, bir olguda preterm doğum, bir olguda düşük 5.dk APGAR skoru ve yenidoğan ünitesine kabul, başka bir olguda doğumda mekonyum boyalı amniyon olduğu tespit edildi.

\section{TARTIŞMA}

Gebeliğin intrahepatik kolestazının patogenezi tam olarak bilinmemektedir. Genetik, çevresel ve hormonal temelleri olan multifaktöriyel bir hastalık olduğu düşünülmektedir [6]. Hepatobiliyer transport mekanizmaları üzerinde yapılan son çalışmalar kolestazın nedenini anlamada yardımcı olmuştur [7]. Hepatobiliyer taşıyıcıların down regülasyonu, örneğin NTCP (Na+/taurocholate cotransporting polypeptide) ki bu taşıyıc1 konjüge safra asit transportunun \%80'inden sorumludur ve safra asit export pompasinın (BSEP) fonksiyonunda bozulma gebelikte kolestaza yatkınlık oluşturan fizyolojik değişiklikler olabilir [8]. Gebelikte artan östrojen ve progesteron, genetik altyapısı kolestaza yatkın olan gebede çevresel faktörlerin de eklenmesiyle kolestaz tablosunun oturmas1na neden olur. Gebeliğin intrahepatik kolestaz1 özellikle östrojen serum konsantrasyonunun pik yaptığı üçüncü trimesterde ve hormon seviyelerinin yüksek olduğu çoğul gebeliklerde daha sık görülür. Ayrıca östrojen dozu yüksek olan oral kontraseptif kullanan hastalarda da kolestaz benzeri tablo görülür [9]. Buna ek olarak deneysel çalıșmalarda hayvanlara verilen östrojen türevleri hepatobiliyer taşıyıcı proteinlerinin (ör: NTCP, BSEP) fonksiyon ve/veya ekspresyonunda bozulmaya neden olmaktadır [10]. Östrojen indirekt etkiyle plazma membran akışkanlığını bozarak da kolestaza neden olabilmektedir. Bu değişiklik hepatik taşıyıcıların etkinliğini bozar. Erken gebelik döneminde doğal progesteron tedavisi alanlarda GIKK riskinin arttı̆̆1 gösterilmiştir. Buna ek olarak GİK olan hastalarda serum ve idrarda sülfatlanmış progesteron ürünlerinin artmış olduğu tespit edilmiştir [11]. Ancak bunun patogenezi net olarak açıklanamamıştır. Obstetrik kolestaz nadiren 25 'inci gebelik haftasından önce görülür; olguların yaklaşı1k \%80'ninde bulgu ve semptomlar 30'uncu gebelik haftasından sonra ortaya çıkar. - 102 - 
Bizim çalışmamızda GİK tanısı ortalama $34.15 \pm 3.1$ gebelik haftasında konulduğu saptand1. Ülkemizde yapılan benzer çalışmalarda Y1ldırım ve ark. GİK tanı gebelik haftas1n1 32.35 \pm 3.78 , Altınbaş ve ark. 34.4 \pm 3.5 hafta olarak bildirmişlerdir. Bizim çalışmamızın GİK ortalama tanı haftasının literatür ile uyumlu olduğu gözlenmiştir $[12,13]$.

Hastaların kliniğinde genellikle geceleri kötüleșen, el ve ayaklarda daha belirgin olmakla birlikte yaygın kaşıntı temel klinik semptomdur. Kaşıntı semptomu preeklampsi, HELLP gibi serum transaminaz değerlerinde yükselme ile giden hastalıkların ayırıcı tanısında yardımcıdır. Karaciğer enzimlerinde yükselme kaşıntıyı takiben oluşabilir. Bazen başvuru anında laboratuvar parametreleri normal sinırlarda izlenebilmekte ve karaciğer fonksiyon testlerinde yükselme semptomun ortaya çıkmasından 2 ile 20 hafta sonrasını bulabilmektedir [14]. Serum transaminazların 1000U/L seviyelerine kadar yükselebildiği bildirilmektedir. Gama-glutamil transpeptidaz ve 5-Nükleotidaz gibi kolestaz olgularında duyarlı olan belirteçler ise diğer kolestatik hastalıkların aksine gebeliğin kolestatik hastalığında sıklıkla normal ya da çok az yüksektir [15]. Çalışmamızda, hasta kayıtlarında 5-Nükleotidaz ve serum safra asitleri düzeyi değerleri olmadığı için bu parametreler incelenememiştir. Hastalarımızda tespit edilen en düşük ve en yüksek serum amino transferaz değerleri sırasıyla AST için 39-642 IU/L iken, ALT için 62-684 IU/L olarak saptandı. Literatürde total safra asitlerindeki $40 \mathrm{mmol} / \mathrm{L}$ üzerindeki değerlerin, hastalığın șiddeti ve fetal komplikasyon sıklığı ile ilişkisi olduğunu bildiren çalışmalar mevcut olsa da [16-18] Rook ve ark. serum safra asitleri dahil laboratuvar bulgularının, fetal komplikasyonların öngörülmesinde kullanılamayacağını bildirmişlerdir [6].

GİK tedavisinde geçmiște steroid, kolestiramin ve S-adenosyl-L-methionine gibi ilaçlar kullanılmış olsa da günümüzde yaygın olarak ursodeoksikolik asit (UDKA) kullanılmaktadir. UDKA serum safra seviyesini ve plasentadan safra asitlerinin geçişini azaltır böylece amniyotik siv1 ve kordon kanında safra asitlerinin seviyesi azalmış olur $[19,20]$. Glantz ve arkadaşları tarafindan yapilan çift-kör, plasebo kontrollü bir çalışmada, GIK tedavisinde UDKA kullanımının, kaşıntı şikayetinin gerilemesinde ve serum biyokimyasal belirteçlerin düzelmesinde steroid kullanımına göre daha etkili olduğu saptanmış fakat her iki tedavinin de fetal komplikasyonları azaltmada etkili olmadığ 1 bildirilmiştir [21]. Bizim çalışmamızda bütün hastalarımıza UDKA tedavisi uyguladık. Olgularımızın hiçbirinde perinatal mortalite saptanmadı. Bunu olgu sayımızın görece az ol- ması ve gebeliğin 37. Haftasından sonra doğum indüksiyonu yolu ile doğumun aktif yönetimi protokolünden kaynaklı olabileceğini düşünmekteyiz. UDKA tedavisi hastalık semptomlar1 ve laboratuvar bulgularını düzeltmede her ne kadar çok etkin olsa da hastalık prevalansının düşük ve perinatal mortalite oranının çok daha düşük olması nedeniyle fetal ölüm oranlarına etkisi açısından güvenilir bir sonuca ulaşmak için çok geniş kapsamlı çalışmalara ihtiyaç vardir [22].

Gebeliğin intrahepatik kolestazının maternal açıdan benign seyirli olduğu, fakat fetal açıdan olumsuz sonuçlarla ilişkili olabileceği bilinmektedir. Bizim çalışmamızda preterm doğum oran1 \%20.59, doğumda 5. dakika APGAR < 7'nin altında olan olgu oran $\% 14,7$ ve doğumda amnion mayisinde mekonyum pasaj1 olan olgu oranı \%14,7 olarak saptandı. Çalışmamızın sonuçları literatür ile benzerlik göstermektedir. Yıldırım ve ark. preterm doğum oranın1 ve mekonyum pasaj1 oranını sirasiyla $\% 19,6$ ve \%17,6 olarak bildirmişlerdir [12]. İsveç'te yapılan 12 yıllık toplum bazlı, tüm GIK doğum verilerini kapsayan çalışmada bizim çalışmamiza benzer şekilde spontane preterm doğum oranının artmış (aOR 1,60; 95\% güven aralığ1 (CI) 1,47-1,93) ve düşük skorlu 5.dk APGAR oranının artmış (aOR 1,45; 95\% CI 1,14-1,85) olduğunu bildirmişlerdir. Yine aynı çalışma da ölü doğum oranında (aOR 0,92 ; 95\% CI 0,521,62) artış olmadığını bildirmişlerdir [22]. Preterm doğumun etiyolojisi henüz netleşmemiştir. Ancak yükselen safra asitleriyle beraber oksitosinin biyoaktivitesinde artış olduğunu, bir başka çalışmada da kolik asitin oksitosin reseptör ekspresyonunu arttırarak preterm doğuma neden olduğu öne sürülmektedir [7]. Fetal ölüm riskinin önüne geçmek için doğumun indüklenmesi yaklaşımı nedeniyle iyatrojenik preterm doğum vakalarında artış bildirilmektedir. Birçok yayında intrauterin fetal ölümlerin özellikle 37. gebelik haftasından sonra ortaya çıktığı vurgulanmıştır. Bu nedenle American College of Obstetricians and Gynecologists (ACOG) GİK tanılı gebelerde, gebeliğin 37.haftasından sonra indüksiyon ile aktif doğum yönetimini önermektedir [5]. Ancak bizim çalışmamızda fetal ölüm gerçekleşmemiştir. Yakın zamanda yayınlanan sistematik bir derlemede sonuç olarak; 53 yıllık periyodda yalnızca 14 yayınlanmış GİK ile ilişkili açıklanamayan fetal ölüm vakası olduğu ve bu nedenle GIK olgularında, aktif doğum indüksiyonu yönteminin gözden geçirilmesi gerektiği önerilmektedir [23]. Royal College of Obstetricians and Gynecologists (RCOG) aktif doğum yönetimini destekleyecek veya reddedecek kanıt olmadığını bu yüzden her hasta için yönetimin kişiselleştirilmesi gerektiğini önermektedir [2]. Her ne kadar perina- 
tal mortalitenin olmaması olgu sayımızın sınırlı olması ile ilişkilendirilirse de, sonucun güncel literatür ile uyumlu olması nedeniyle gebeliğin 37.haftasindan sonra indüksiyon ile aktif doğum yönetimi yerine doğum yönetiminin hastaya göre kişiselleştirilmesini önermekteyiz.

Bizim çalıșmamızda GİK tanılı gebelerde GDM komorbiditesi oranını \%15.62 olarak saptadık. Literatürde yeni bir bulgu olarak, yüksek GIKK ve GDM komorbiditesini saptayan iki çalışma mevcuttur. Martineau ve ark. yaptığı çalışma da GIKK tanılı gebelerde GDM oranının $\% 13,6$ olduğunu, GDM'nin GİK gelișimi için yatkınlık yarattığını bildirmişlerdir. Hem safra asidi reseptörü hem de glukoz ve lipid homeostazında görev alan farnesoid X receptor (FXR) düzeyinin azalmış olmasıyla ilişkili olabileceği hipotezi öne sürülmektedir. Ayrıca GİK tanısı konulmuş gebelerde tekrar GDM taramasinın değerlendirilmesini önermektedirler [1, 24].

GDM olan beş olgumuzun yenidoğan sonuçları incelendiğinde, komorbidite sonucu daha fazla oranda olumsuz yenidoğan sonuçlar1 gözlenmiş olsa da GDM olgu sayımızın s1nırlı olması nedeniyle istatistiki karşılaştırma yapılamamıştır. GIK ve GDM komorbiditesi konusunda daha geniș kapsamlı çalıșmalara ihtiyaç vardır. Obstetrik özgeçmişleri değerlendirildiğinde, üç olguda daha önceki gebeliklerinde GIKK tanısı ile tedavi aldıkları saptand1. İki olgumuzda ise GİK tanısı laboratuvar ile desteklenmemiş olmasına rağmen, daha önceki gebeliklerinin son ayında başlamış ve doğum sonrası gerilemiș olan özellikle avuç içi ve ayak tabanı bölgelerinde belirgin kaşıntı şikayeti öyküsünün olduğu tespit edildi. Kenyon ve ark. çalışmasında, klasik avuç içi ve ayak tabanında kaşıntısı olan fakat karaciğer fonksiyon testleri ve serum safra asitleri düzeyi normal olan gebelerin takibinde, ortanca 4.5 hafta (2-20 hafta) sonra GIIK tanısinda kullanılan laboratuvar parametrelerinden bir veya daha fazlasının yükseldiğini bildirmişlerdir [14]. Bu nedenle mevcut gebeliklerinde tanı konulmamış özellikle avuç içi ve ayak tabanı bölgelerinde belirgin kaşıntı şikayeti olan hastaların takibinde GIKK tanısına yönelik laboratuvar parametrelerinin haftalık tekrarlanmasını önermekteyiz.

Sonuç olarak yaptı̆̆ımız çalışma ve incelenen literatür sonucunda GİK yönetimi ile ilgili bir konsensüs bulunmamakla birlikte doğum zamanlamasının ve obstetrik risk yönetiminin hastaya göre özel planlanmasını önermekteyiz. Aynı zamanda gebeliğin intrahepatik kolestazı tanılı hastalarda gestasyonel diyabetes mellitus komorbidite riskinin artmış olmasının, hastalığın izleminde dikkate alınması gerektiğini düşünmekteyiz.

\section{KAYNAKLAR}

1. Wikström Shemer E, Marschall HU, Ludvigsson JF, Stephansson $O$. Intrahepatic cholestasis of pregnancy and associated adverse pregnancy and fetal outcomes: a 12-year population-based cohort study. BJOG 2013;120:717-23.

2. Royal College of Obstetricians and Gynecologists. Obstetric cholestasis: Green-top Guideline no. 43. London:RCOG; 2011

3. Geenes V, Williamson C. Intrahepatic cholestasis of pregnancy. World J Gastroenterol 2009; 15:2049-66.

4. Henderson CE, Shah RR, Gottimukkala S, Ferreira KK, Hamaoui A, Mercado R. Primum non nocere: how active management became modus operandi for intrahepatic cholestasis of pregnancy. Am J Obstet Gynecol. 2014 Article in press doi: 10.1016/j.ajog.2014.03.058

5. American College of Obstetricians and Gynecologists. Medically indicated late preterm and early term deliveries. Committee Opinion no. 560. Obstet Gynecol 2013;121:908-10

6. Rook M, Vargas J, Caughey A, Bacchetti P, Rosenthal P, Bull L. Fetal outcomes in pregnancies complicated by intrahepatic cholestasis of pregnancy in a Northern California cohort. PLoS One. 2012;7(3):e28343. doi: 10.1371/journal.pone.0028343

7. Yılmaz S, Üstün Y,Hizlı D, Deveer R. Gebeliğin Intrahepatik Kolestazı. Gazi Med J 2012; 23: 138-44

8. Wagner M, Trauner M. Transcriptional regulation of hepatobiliary transport systems in health and disease: implications for a rationale approach to the treatment of intrahepatic cholestasis. Ann Hepatol 2005; 4: 77-99.

9. Reyes H, Simon FR. Intrahepatic cholestasis of pregnancy: an estrogen related disease. Semin Liver Dis 1993; 13: 289301.

10. Geier A, Wagner M, Dietrich CG, Trauner M. Principles of hepatic organic anion transporter regulation during cholestasis, inflammation and liver regeneration. Biochim Biophys Acta 2007; 1773: 283-308.

11. Reyes H, Sjovall J. Bile acids and progesterone metabolites in intrahepatic cholestasis of pregnancy. Ann Med 2000; 32: 94-106.

12. Yıldırım G, Aslan H, Gedikbaşı A, et al. İntrahepatik kolestazda gebelik sonuçları. Türk Jinekoloji ve Obstetrik Derneği Dergisi 2007; 4: 250-253.

13. Altınbaş ŞK, Karçaaltıncaba D, Kandemir Ö, Yalvaç S. Intrahepatik gebelik kolestazı: 33 vakanın maternal ve fetal sonuçlarının değerlendirilmesi. Bakırköy Tip Dergisi 2013;4:171-175.

14. Kenyon, A. P., Piercy, C. N., Girling, J., Williamson, C., Tribe, R. M., \& Shennan, A. H. Pruritus may precede abnormal liver function tests in pregnant women with obstetric cholestasis: a longitudinal analysis. BJOG: An International Journal of Obstetrics \& Gynaecology, 2001, 108.11: 1190-1192.

15. Davidson KM. Intrahepatic cholestasis of preganancy. Seminars in Perinatology 1998; 22: 104- 11. 
16. Brites D, Rodrigues CM, van Zeller H, Brito A, Silva R. Relevance of serum bile acid profile in the diagnosis of intrahepatic cholestasis of pregnancy in an high incidence area: Portugal. Eur J Obstet Gynecol Reprod Biol 1998; 80: 31-38.

17. Pata O, Vardarel> E, Ozcan A, Serteser M, Unsal I, Saruç $M$, et al. Intrahepatic cholestasis of pregnancy: correlation of preterm delivery with bile acids. Turk J Gastroenterol 2011; 22:602-5.

18. Geenes V, Chappell LC, Seed PT, Steer PJ, Knight M, Williamson C. Association of severe intrahepatic cholestasis of pregnancy with adverse pregnancy outcomes: a prospective population-based case-control study. Hepatology2013;26617. http://dx.doi.org/10.1002/hep.26617

19. Mazella G, Nicola R, Franceso A, Patrizia S, Luciano B, Anna $M$, et al. Ursodeoxycholic acid administration in patients with cholestasis of pregnancy; effects on primary bile acids in babies and mothers. Hepatology 2001; 33: 504- 8.

20. Geenes V, Lövgren-Sandblom A, Benthin L, Lawrance D, Chambers J, et al. (2014) The Reversed Feto-Maternal Bile Acid Gradient in Intrahepatic Cholestasis of Pregnancy Is Corrected by Ursodeoxycholic Acid. PLoS ONE 9(1): e83828. doi:10.1371/journal.pone.0083828
21. Glantz A, Marschall HU, Lammert F, Mattsson LA. Intrahepatic of pregnancy: a randomized control trial comparing dexamethasone and ursodeoxycholic acid. Hepatology 2005; 42(6): 1399-1405

22. Chappell LC, Gurung V, Seed PT, Chambers J, Williamson C, Thornton JG; PITCH Study Consortium. Ursodeoxycholic acid versus placebo, and early term delivery versus expectant management, in women with intrahepatic cholestasis of pregnancy: semifactorial randomised clinical trial. BMJ. 2012 Jun 13;344:e3799. doi: 10.1136/bmj.e3799

23. Henderson CE, Shah RR, Gottimukkala S, Ferreira KK, Hamaoui A, Mercado R. Primum non nocere: how active management became modus operandi for intrahepatic cholestasis of pregnancy. Am J Obstet Gynecol. 2014 Apr 1. pii: S00029378(14)00327-5. doi: 10.1016/j.ajog.2014.03.058

24. Martineau M, Raker C, Powrie R, Williamson C. Intrahepatic cholestasis of pregnancy is associated with an increased risk of gestational diabetes. Eur J Obstet Gynecol Reprod Biol. 2014 May;176:80-5. doi: 10.1016/j.ejogrb.2013.12.037 